\title{
Serum Adiponectin and Leptin as Predictors of the Presence and Degree of Coronary Atherosclerosis
}

\author{
Nashwa A. Abd El-Mottaleb, Hosam H. Ali*, Hosny B. Hamed**, \\ Alaa A. Abd-Elsayed *** \\ Departments of Physiology, Cardiovascular Medicine*, Clinical \\ Pathology**, Public Health and Biostatestics***; South Egypt Cancer \\ Institute**, Faculty of Medicine, Assiut University
}

\begin{abstract}
Background: Recently, the adipocyte derived proteins; adiponectin and leptin, have been found to be associated with obesity, type 2 diabetes, insulin resistance, hyperinsulinemia, dyslipidemia and the presence of coronary artery disease. However, the association of these proteins with the degree of coronary atherosclerosis has not been not been well elucidated. Objectives: To determine the relationship between serum adiponectin and leptin levels and the presence and degree of coronary atherosclerosis. Methods: Seventy patients performing diagnostic coronary angiography in our catheterization laboratory for the investigation of coronary artery disease (CAD) were recruited. The control group included (20 subjects) who were non-diabetics, non-hypertensives, with no history of previous acute coronary syndrome, having normal ECG, of matched age, sex, body mass index (BMI), and waist/hip ratio, performing coronary angiography for stable angina with inadequate exercise test results, and proved to have a completely normal coronary angiography. All cases and control were subjected to complete history and clinical examination including 12 lead ECG, measurement of BMI, and hip/waist ratio. Fasting blood glucose, full lipogram, serum adiponectin, and serum leptin were measured. Angiographic evaluation of coronary atherosclerosis was performed by assessing three atherosclerotic indices; severity (transverse disease), extent (longitudinal disease), and pattern (lesion complexity). Results: The independent predictors of the atherosclerosis lesion severity were larger waist/hip ratio (beta, 0.34), followed by higher LDL-cholesterol (beta, 0.32), low serum adiponectin level (beta, -0.23), older age (beta, 0.19), higher leptin level (beta, 0.17), current unstable angina (beta, 0.17), and finally previous myocardial infarction (MI) (beta, 0.14). This model is a good one as indicated from the model adjusted $r^{2}(50 \%)$. For the extent of atherosclerosis index lower serum adiponectin level was by far the most important independent predictor (beta, -0.45), followed by higher LDL-cholesterol (beta, 0.23), older age and previous MI (beta, 0.21 for both), while higher serum leptin level was only a univariate predictor. The model adjusted $r^{2}$ was $65 \%$. For the atherosclerosis pattern index, the independent predictors were previous MI (beta, 0.31), lower serum adiponectin level (beta, -0.29), larger waist/hip ratio (beta, 0.26), higher serum leptin level (beta, 0.24), older age (beta, 0.22), and higher fasting blood glucose level (beta, 20). The model adjusted $r^{2}$ was $62 \%$. Conclusion: Both serum adiponectin and leptin
\end{abstract}


might play an important pathogenic role not only in the occurrence but also in the severity, extent and lesion complexity in CAD patients.

Key Words: adiponectin; leptin; severity; extent; pattern; coronary atherosclerosis.

\section{INTRODUCTION}

Atherosclerotic cardiovascular complications are major causes of morbidity and mortality. The precise mechanism underlying the development of atherosclerotic vascular disease has not been fully elucidated. ${ }^{(1)}$

Adiponectin is a protein hormone secreted exclusively by adipocytes. It is a member of the adiposecreted proteins termed 'adipocytokines' or 'adipokines ${ }^{\text {(2) }}$. Adiponectin binds to two different seven-transmembrane domain receptors called 'AdipoR1' and 'AdipoR2'. AdipoR1 and AdipoR2 are clearly involved in energy metabolism but have opposite effects. Adipo R1 is predominantly expressed in skeletal muscle, whereas Adipo R2 is predominantly expressed in liver and throughout the $\operatorname{brain}^{(3)}$. Many other cells have adiponectin receptors (macrophages, osteoblasts, adipocytes, endothelial and muscular cells of the vascular wall, pancreatic cells and central nervous system cells) ${ }^{(4)}$.

Adiponectin has been proposed to exhibit a protective effect against atherosclerosis. It is involved in glucose and lipid metabolism ${ }^{(5)}$. It has been found that hypoadiponectinemia is associated with obesity, type 2 diabetes, insulin resistence, hyperinsulinemia (6) and dyslipidemia ${ }^{(7)}$. Furthermore, patients with hypoadiponectinemia are found to be at increased risk of myocardial infarction $(\mathrm{MI})^{(8)}$.
Leptin, the product of the obese gene, is mainly produced by adipocytes $^{(9)}$. Leptin is a satiety factor that regulates body weight by inducing a decrease in food intake and an increase in energy consumption ${ }^{(10)}$. Plasma leptin concentrations reflect the amount of adipose tissue and they positively correlate with the insulin resistance ${ }^{(11)}$.

Furthermore, leptin is involved in a number of diverse physiological processes, such as regulation of endocrine functions, inflammation, immune response, reproduction, and angiogenesis ${ }^{(\mathbf{1 2})}$.

Leptin receptors have been also identified in various peripheral tissues, including in the cardiovascular system and in human coronary arteries. It seems to have both vasodilatory and vasoconstrictory actions on vascular endothelium ${ }^{(13)}$. The exact role of leptin in cardiac and vascular homeostasis is still not fully understood $^{(14)}$.

\section{OBJECTIVES}

To determine the relationship between serum adiponectin and leptin levels and the presence and degree of coronary atherosclerosis.

\section{MATERIALS \& METHODS}

\section{Subjects:}

Seventy consecutive patients performing diagnostic cardiac catheterization in Assiut University Hospital Catheterization Laboratory for the investigation of coronary 
artery disease (CAD) were recruited. Patients were excluded if they had peroxisome proliferator-activated receptor (PPAR)-alpha or PPARgamma agonists, concurrent inflammatory or neoplastic disease, hemodynamically significant valvular heart disease, or prior revascularization procedure. The control group included (20 subjects) who were non-diabetics, nonhypertensives, with no history of a previous acute coronary syndrome, having normal ECG, of matched age, sex, BMI, and waist/hip ratio, performing coronary angiography for stable angina with inadequate exercise test results and proved to have a completely normal coronary angiography. The study was approved by Assiut faculty of medicine ethical committee. All patients and controls gave an informed consent to the study protocol. All cases and control were subjected to complete history and clinical examination including 12 lead ECG, measurement of body mass index (BMI), and waist/hip ratio (WHR).

\section{Laboratory measurements:}

Fasting blood samples were obtained before angiography. Serum was separated immediately by centrifugation and kept at $-20^{\circ} \mathrm{C}$ until analysis. Serum adiponectin concentration was assayed with an adiponectin ELISA kit (Biovendor Laboratory Medicine, Inc., Czech Republic). Serum Leptin was assayed with human leptin ELISA kit (DRG international, Inc., Germany). Total cholesterol, triglyceride, high density lipoprotein (HDL)-cholesterol and glucose levels were measured by enzymatic colorimetric method using reagents from (Human Gesellschaft fur Biochemica Diagnostica $\mathrm{mbH}$, Germany). Low density lipoprotein LDL-cholesterol was calculated by Friedewald's formula ${ }^{(15)}$.

\section{Evaluation of coronary atherosclerosis by angiogram:}

Angiographic evaluation of coronary atherosclerosis was performed by assessing three atherosclerotic indices; severity and extent using the criteria of Bogaty et al. ${ }^{(16)}$ and pattern of the lesion was assessed according to Scanlon et al. (17)

Severity pertains exclusively to the degree of narrowing (transverse disease), and was evaluated by counting the number of major epicardial vessels with $\geq 70 \%$ narrowing of the lumen diameter. The maximum number of vessels was three. Left main stenosis $\geq 50 \%$ was counted as two vessels.

Extent considers the proportion of each coronary segment that appears abnormal (longitudinal disease). The coronary arteries were classified into 15 segments; one is the left main, 5 in the left anterior descending (proximal, mid, distal and 2 diagonals), 4 in the non-dominant left circumflex (proximal, distal and 2 obtuse marginals), and 5 in the dominant right coronary (proximal, mid and distal, posterior descending and posterior left ventricular arteries). For each of these segment a score ranged from 0-3 was given as according to the length of the abnormal segment (narrowed and/or irregular) as follows; 0 if angiographically normal, 1 if $\leq 10 \%$ abnormal, 2 if $>10 \%$ to $50 \%$ abnormal, and 3 if $>50 \%$ abnormal. Then, the extent index was 
calculated by dividing the extent score calculated from the segments seen by antegrade flow divided by their number; thus it could range from 0 (score of 0 ) to a maximum of 3 (score of 45 divided by 15).

Pattern describes the complexity of the atherosclerotic lesion. A pattern score was obtained from each of the 15 segments above ranging from 0 to 3 according to the lesion complexity described in the American College of Cardiology/American Heart Association classification (17) as follows; 0 if normal, 1 if type A lesion, 2 if type B lesion, and 3 if type $\mathrm{C}$ lesion. Then, the pattern index was calculated the same way as the extent index by dividing the pattern score calculated from the segments seen by antegrade flow divided by their number.

\section{Statistical analysis:}

All data were analyzed using SPSS (Statistical Program for Social Sciences version 14 for windows, 2006, SPSS Inc., Chicago, IL, USA). Continuous variables were expressed as mean \pm standard deviation (SD) and discrete variables were presented as frequencies and percentages. Continuous variables were compared between the two groups using the unpaired Student's t test for normally distributed data and the MannWhitney $U$ test for non-normally distributed data. Discrete variables were compared using Chi-Square test. For each of the atherosclerosis indices, the univariate predictors were determined by Pearson correlation for the continuous variables and Spearman correlation for discrete variables. For each of the indices the significant univariate predictors were entered in a stepwise multivariate regression model to determine the independent predictors. Statistical significance was defined as a $\mathrm{P}$ value $<0.05$.

\section{RESULTS}

The clinical and laboratory characteristics of the study groups are shown in table 1. The patients group included 22 diabetics $(31 \%), 42$ hypertensive patients $(60 \%), 36$ patients $(51 \%)$ with previous unstable angina, and 34 patients (49\%) with a previous myocardial infarction (MI). Compared to the control group; the patient group had significantly lower adiponectin, and HDL-cholesterol levels and higher leptin, fasting blood glucose, total cholesterol, and LDLcholesterol levels.

The predictors of the severity, extent and pattern indexes of coronary atherosclerosis are shown in tables 2 , 3 , 4 respectively. The independent predictor of the atherosclerosis lesion severity was larger waist/hip ratio (beta (0.34), followed by higher LDLcholesterol (beta, 0.32), low serum adiponectin level (beta, -0.23), older age (beta, 0.19), higher leptin level (beta, 0.17), current unstable angina (beta, 0.17), and finally previous MI. This model is a good one as indicated from the model adjusted $r^{2}(50 \%)$.

For the extent of atherosclerosis index lower serum adiponectin level was by far the most important independent predictor (beta, -0.45), followed by higher LDL-cholesterol (beta, 0.23), older age and previous MI (beta, 0.21 for both), while higher serum leptin level was only a 
univariate predictor. The model adjusted $\mathrm{r}^{2}$ was $65 \%$.

For the atherosclerosis pattern index, which represents the lesion complexity, the independent predictors were previous MI (beta, 0.31 ), lower serum adiponectin level (beta, -0.29), larger waist/hip ratio (beta, 0.26), higher serum leptin level (beta, 0.24), older age (beta, 0.22), and higher fasting blood glucose level (beta, 20). The model adjusted $\mathrm{r}^{2}$ was $62 \%$.

Table 1: Clinical and laboratory characteristics of the patients versus the control group

\begin{tabular}{llll}
\hline & Patients (70) & Control (20) & P value \\
\hline Age & $55.7 \pm 12$ & $51.8 \pm 11$ & $\mathrm{NS}$ \\
Male gender & $60(86 \%)$ & $16(80 \%)$ & \\
Body mass index & $29.3 \pm 3.7$ & $28.6 \pm 4.5$ & $\mathrm{NS}$ \\
Waist/hip ratio & $0.99 \pm 0.12$ & $0.95 \pm 0.09$ & $\mathrm{NS}$ \\
Current Smoker & $36(51 \%)$ & $7(35 \%)$ & $\mathrm{NS}$ \\
Previous smoker & $14(20 \%)$ & $6(30 \%)$ & $\mathrm{NS}$ \\
Systolic blood pressure & $125 \pm 34$ & $118 \pm 9$ & $\mathrm{NS}$ \\
Diastolic blood pressure & $82 \pm 14$ & $79 \pm 8$ & $\mathrm{NS}$ \\
Adiponectin level ( $\mu \mathrm{g} / \mathrm{dL})$ & $8.7 \pm 4.9$ & $12.7 \pm 4.4$ & 0.001 \\
Leptin (ng/mL) & $29.7 \pm 12.7$ & $13.9 \pm 6.0$ & $<0.0001$ \\
Fasting blood glucose (mmol/L) & $8.0 \pm 4.1$ & $5.2 \pm 0.7$ & 0.004 \\
Triglycerides (mg/dL) & $299 \pm 75$ & $226 \pm 107$ & $\mathrm{NS}$ \\
Cholesterol (mg/dL) & $222 \pm 45$ & $195 \pm 18$ & 0.01 \\
LDL-cholesterol (mg/dL) & $144 \pm 41$ & $102 \pm 45$ & $<0.0001$ \\
HDL- cholesterol (mg/dL) & $31 \pm 10$ & $41 \pm 4$ & $<0.0001$ \\
\hline
\end{tabular}

NS; not significant 
Table 2: Predictors of the severity of coronary atherosclerosis

\begin{tabular}{|c|c|c|c|c|c|}
\hline & \multicolumn{2}{|c|}{ Univariate Predictors } & \multicolumn{2}{|l|}{ Multivariate Predictors } & \multirow[b]{2}{*}{ p value } \\
\hline & $\mathbf{r}$ & p value & $\mathrm{B}(95 \% \mathrm{CI})$ & Beta & \\
\hline Age & 0.37 & $<0.0001$ & $0.02(0.01-0.03)$ & 0.19 & 0.004 \\
\hline Male gender & 0.03 & NS & & & \\
\hline Body mass index & 0.003 & NS & & & \\
\hline Waist/hip ratio & 0.52 & $<0.0001$ & $3.3(2.0-4.7)$ & 0.34 & $<0.0001$ \\
\hline Current Smoker & 0.04 & NS & & & \\
\hline Previous or current smoker & 0.06 & NS & & & \\
\hline Systolic blood pressure & 0.21 & 0.05 & & & \\
\hline Diastolic blood pressure & 0.09 & NS & & & \\
\hline Diabetes & 0.43 & $<0.0001$ & & & \\
\hline Previous myocardial infarction & 0.24 & 0.02 & $0.32(0.02-0.62)$ & 0.14 & 0.04 \\
\hline Current unstable angina & 0.32 & 0.002 & $0.37(0.09-0.66)$ & 0.17 & 0.01 \\
\hline Adiponectin level $(\mu \mathrm{g} / \mathrm{dL})$ & -0.63 & $<0.0001$ & $-0.05(-0.08--0.02)$ & -0.23 & 0.003 \\
\hline Leptin $(\mathrm{ng} / \mathrm{mL})$ & 0.43 & $<0.0001$ & $0.01(0.003-0.026)$ & 0.17 & 0.01 \\
\hline Fasting blood glucose $(\mathrm{m} \mu \mathrm{mol} / \mathrm{L})$ & 0.21 & 0.04 & & & \\
\hline Triglycerides (mg/dL) & 0.20 & NS & & & \\
\hline Cholesterol (mg/dL) & 0.44 & $<0.0001$ & & & \\
\hline LDL-cholesterol (mg/dL) & 0.60 & $<0.0001$ & $0.008(0.005-0.012)$ & 0.32 & $<0.0001$ \\
\hline HDL- cholesterol (mg/dL) & -0.40 & $<0.0001$ & & & \\
\hline
\end{tabular}

$N S$; not significant 
Table 3: Predictors of the extent index of atherosclerosis

\begin{tabular}{|c|c|c|c|c|c|}
\hline & \multicolumn{2}{|c|}{ Univariate Predictors } & \multicolumn{2}{|c|}{ Multivariate Predictors } & \multirow[b]{2}{*}{$P$ value } \\
\hline & $\mathbf{r}$ & P value & B $(95 \% C I)$ & Beta & \\
\hline Age & 0.35 & 0.001 & $0.005(0.001-0.009)$ & 0.21 & 0.008 \\
\hline Male gender & 0.11 & NS & & & \\
\hline Body mass index & 0.02 & NS & & & \\
\hline Waist/hip ratio & 0.29 & 0.006 & & & \\
\hline Current Smoker & 0.004 & NS & & & \\
\hline Previous smoker & 0.14 & NS & & & \\
\hline Systolic blood pressure & 0.16 & NS & & & \\
\hline Diastolic blood pressure & 0.13 & NS & & & \\
\hline Diabetes & 0.30 & 0.005 & & & \\
\hline Previous myocardial infarction & 0.26 & 0.01 & $0.13(0.03-0.22)$ & 0.21 & 0.008 \\
\hline Current unstable angina & 0.28 & 0.008 & & & \\
\hline Adiponectin level $(\mu \mathrm{g} / \mathrm{dL})$ & -0.62 & $<0.0001$ & $-0.03(-0.4--0.02)$ & -0.46 & $<0.0001$ \\
\hline Leptin $(\mathrm{ng} / \mathrm{mL})$ & 0.40 & $<0.0001$ & & & \\
\hline Fasting blood glucose $(\mathrm{mmol} / \mathrm{L})$ & 0.25 & 0.02 & & & \\
\hline Triglycerides $(\mathrm{mg} / \mathrm{dL})$ & 0.04 & NS & & & \\
\hline Cholesterol (mg/dL) & 0.36 & $<0.0001$ & & & \\
\hline LDL-cholesterol (mg/dL) & 0.48 & $<0.0001$ & $0.002(0.001-0.003)$ & 0.23 & 0.007 \\
\hline HDL- cholesterol (mg/dL) & -0.43 & $<0.0001$ & & & \\
\hline
\end{tabular}

NS; not significant 
Table 4: Predictors of the pattern index of atherosclerosis

\begin{tabular}{|c|c|c|c|c|c|}
\hline & \multicolumn{2}{|c|}{ Univariate Predictors } & \multicolumn{2}{|c|}{ Multivariate Predictors } & \multirow[b]{2}{*}{ P value } \\
\hline & $\mathbf{r}$ & $P$ value & B (95\%CI) & Beta & \\
\hline Age & 0.35 & 0.001 & $0.004(0.001-0.006)$ & 0.22 & 0.003 \\
\hline Male gender & 0.01 & NS & & & \\
\hline Body mass index & 0.05 & NS & & & \\
\hline Waist/hip ratio & 0.35 & 0.001 & $0.44(0.18-0.71)$ & 0.26 & 0.001 \\
\hline Current Smoker & 0.08 & NS & & & \\
\hline Previous smoker & 0.09 & NS & & & \\
\hline Systolic blood pressure & 0.08 & NS & & & \\
\hline Diastolic blood pressure & 0.04 & NS & & & \\
\hline Diabetes & 0.38 & $<0.0001$ & & & \\
\hline Previous myocardial infarction & 0.41 & $<0.001$ & $0.12(0.07-0.18)$ & 0.31 & $<0.0001$ \\
\hline Current unstable angina & 0.14 & NS & & & \\
\hline Adiponectin level ( $\mu \mathrm{g} / \mathrm{dL})$ & -0.61 & $<0.0001$ & $-0.01(-0.02--0.005)$ & -0.29 & 0.001 \\
\hline Leptin (ng/mL) & 0.45 & $<0.0001$ & $0.003(0.001-0.006)$ & 0.24 & 0.002 \\
\hline Fasting blood glucose (mmol/L) & 0.36 & 0.001 & $0.01(0.003-0.017)$ & 0.20 & 0.02 \\
\hline Triglycerides (mg/dL) & 0.2 & NS & & & \\
\hline Cholesterol (mg/dL) & 0.25 & 0.02 & & & \\
\hline LDL-cholesterol (mg/dL) & 0.42 & $<0.0001$ & & & \\
\hline HDL- cholesterol (mg/dL) & -0.41 & $<0.0001$ & & & \\
\hline
\end{tabular}

NS; not significant 


\section{DISCUSSION}

Adipose tissue is not only an organ of energy storage but also a secretory organ producing a variety of bioactive substances, including adiponectin, leptin, tumour necrosis factor- $\alpha$ (TNF- $\alpha$ ), and plasminogen activator inhibitor type 1 (PAI-1) that may contribute directly to the development of vascular disease ${ }^{(18)}$.

This study confirms the previous reports that plasma adiponectin levels are lower in patients with coronary atherosclerosis ${ }^{\mathbf{( 1 9 - 2 2})}$ and that it is, on multivariate analysis, an independent predictor of the 3 aspects of the degree of coronary artery disease (extent, severity and complexity $)^{(21,23,24)}$. However, Lim et al. ${ }^{(20)}$ found no significant relation between serum adiponectin and the extent or severity of coronary atherosclerosis.

One of the initial steps in atherogenesis is adherence of monocytes to endothelial cells and their migration into the subendothelial space, where they take up oxidized lipoproteins and transform into foam cells ${ }^{(25)}$. Plasma adiponectin rapidly accumulates in the subendothelial space of the injured human artery ${ }^{(26)}$. In physiologic concentration, adiponectin has a dose-dependent inhibitory effect of TNF- $\alpha$ mediated expression of vascular cell adhesion molecules-1, endothelial-leucocyte adhesion molecule and intracellular adhesion molecule-1 thus it inhibits monocyte adhesion to endothelial cells and foam cell formation ${ }^{(\mathbf{1 8}, 27)}$. Additionally, TNF- $\alpha$ has stimulatory effects on PAI-1 release from adipocytes, $\left.{ }^{(28,}{ }^{29}\right)$. PAI-1 has an important regulatory role in fibrinolytic processes and thrombus formation. Adiponectin also binds to platelet-derived growth factor-BB and subendothelial collagens and suppresses proliferation and migration of vascular smooth muscle cell, therefore limiting the progression of atherosclerosis and re-stenosis ${ }^{(27,30)}$.

Moreover, adiponectin exerts its vascular actions by direct stimulation of nitric oxide production in endothelial cells and taking part in vasodilatator actions and increasing blood flow. ${ }^{(31)}$

Studies in experimental animals have shown that adiponectin has the potential to inhibit neointimal formation ${ }^{(30,32)}$. Kubota et al. (32) reported that adiponectin-deficient mice have severe neointimal thickening and increased proliferation of vascular smooth muscle cells in mechanically injured arteries. In these mice, neointimal proliferation is attenuated by adenovirus-mediated adiponectin administration ${ }^{(25)}$.

In this study, the patients group showed increased levels of fasting blood glucose, total cholesterol, and LDL-cholesterol but HDL-cholesterol decreased with decrease in adiponectin concentration. These findings may suggest that adiponectin may lead to vasculoprotection through improvement of lipid metabolism. Adiponectin suppresses lipid accumulation in macrophages, resulting in markedly decreased uptake of oxidized LDL and inhibition of foam cell formation (33). Adiponectin induces AMP activated protein kinase, resulting in stimulation of glucose uptake in muscle, fatty acid oxidation in muscle and liver and 
decrease of hepatic glucose production, cholesterol and triglyceride synthesis and lipogenesis (34). Therefore, increased blood lipid concentrations in this study may be explained by our results which showed decreased concentrations of adiponectin in the patients group.

In the present study, WHR was an independent predictor of severity and pattern of coronary atherosclerosis. Increased WHR may be a sign of higher waist circumference (reflecting increased visceral fat, a cardiovascular disease (CVD) risk factor), reduced hip circumference (reflecting low gluteal muscle mass and/or low peripheral fat mass), or a combination of these. High gluteal muscle mass and high peripheral fat may protect against CVD ${ }^{(35,36)}$.

There are several mechanisms through which visceral fat may promote CVD. 1) Visceral fat leads to an increase in adipokines including leptin which may promote atherosclerosis $^{(37)}$. 2) Proteins that are potentially protective against the development of CVD (adiponectin, and peroxisome proliferator activated receptor-gamma) have lower levels of expression in visceral fat compared to the subcutaneous fat ${ }^{(38)}$. 3) Visceral fat has more beta-adrenergic receptors and a decreased function of antilipolytic receptors, which leads to higher rates of catecholaminestimulated lipolysis and free fatty acids (39). 4) Visceral fat produces more PAI-1, an inhibitor of fibrinolysis compared with subcutaneous fat ${ }^{(\mathbf{4 0})}$, while expression of angiotensinogen, a potential regulator of blood pressure, is also higher in visceral fat ${ }^{\mathbf{( 4 1 )}}$.

In the current study, BMI wasn't a predictor of the degree of coronary atherosclerosis. The lack of agreement between WHR and BMI may reflect that these measures identify different distributions of fat (central obesity in case of WHR vs. subcutaneous/total fat in case of BMI). Notably, BMI assesses the entire body mass without differentiating between its components, namely muscle, visceral fat, subcutaneous fat, bone and fluid (42)

The functional integrity of the vascular endothelium exerts antiatherosclerotic and anti-thrombotic effects ${ }^{(43)}$. Conversely, impaired endothelium-dependent coronary vasomotor function describes a proatherosclerotic state ${ }^{(\mathbf{4 4})}$.

In the present study, serum leptin levels were higher in patients with coronary atherosclerosis than controls. Serum leptin was correlated positively with the severity, extent and pattern of coronary atherosclerosis. However, on multivariate analysis, the high level of serum leptin was independent factors affecting the severity and pattern only, but not the extent of coronary atherosclerosis. Leptin was previously reported to be an independent predictor of CAD ${ }^{(45,46)}$. However, other investigators emphasized a potential protective role of leptin in CAD ${ }^{(47,48,49)}$.

Functional leptin receptors are present on endothelial cells. However, the actions of leptin to modulate endothelial function remain controversial (50). Leptin can elicit changes that may be detrimental to cardiovascular health. Its 
administration may stimulate increases in oxidative stress in in vitro cultured human endothelial cells ${ }^{(51)}$. The increase in oxidative stress may interact with nitric oxide to form peroxynitrite and, thereby, decrease the bioavailability of nitric oxide, which is associated with an impairment of endothelium-dependent vasodilation $^{\mathbf{( 5 2 )}}$. Leptin also promotes neointimal growth in mice (53) $^{\text {and }}$ stimulates migration and proliferation of vascular smooth muscle cells ${ }^{(54)}$.

Leptin stimulates synthesis and secretion of endothelin-1, a potent vasoconstrictor and mitogen ${ }^{(55)}$. Leptin also correlates positively with plasma concentration of PAI-1, fibrinogen, and von Willebrand factor $(\mathbf{5 6 , 5 7 , 5 8 )}$ and promotes ADP-induced platelet aggregation ${ }^{(59)}$. It potentiates production of inflammatory cytokines, e.g., TNF- $\alpha$, and interleukins 2 and 6 in cells (60). Leptin stimulates lipoprotein lipase secretion in macrophages (61) and increases accumulation of cholesterol esters in foam cells, especially at high glucose concentrations ${ }^{(62)}$. Leptin promotes hepatic HDL and decreases plasma HDL level in mice ${ }^{(63)}$. Moreover, it causes sympathetic activation, pressor responses ${ }^{(64)}$.

In contrast, there is evidence supporting several potentially beneficial effects of leptin. Momin et al. ${ }^{(65)}$ reported that leptin is an endothelium-independent vasodilator in saphenous vein and internal mammary artery vascular rings isolated from patients with CAD. These vascular effects in an isolated preparation are independent of any neurally mediated actions of leptin. They are consistent with several previous reports demonstrating leptininduced coronary artery vasodilation in humans and activation of endothelial nitric oxide production in human aortic endothelial cells ${ }^{(66)}$.

Leptin may also activate adult human endothelial progenitor cells and promote angiogenesis ${ }^{(67)}$.Under normoglycemic conditions leptin may protect macrophages from cholesterol overload $^{(\mathbf{6 8 )}}$. This apparent discrepancy between the potentially protective actions of leptin, and its association with impaired cardiovascular outcome in epidemiological studies, may be reconciled by several explanations, including: first, the broad spectrum of cardiovascular actions of leptin; second, dose dependent effects of leptin; and third, the concept of selective leptin resistance ${ }^{(\mathbf{1 4})}$.

\section{Conclusion:}

Both serum adiponectin and leptin might play an important pathogenic role not only in the occurrence but also in the severity, extent and lesion complexity in CAD patients. Waist/hip ratio, probably reflecting visceral obesity, is an important predictor of the degree of coronary atherosclerosis.

\section{REFERENCES}

1. Dzielińska $Z$, Januszewicz A, Wiecek A, Demkow M, Makowiecka-Cieśla M, Prejbisz A, Kadziela J, Mielniczuk R, Florczak E, Janas J, Januszewicz $M$ and Ruzyllo W (2003): Decreased plasma concentration of a novel anti-inflammatory protein adiponectin in hypertensive men 
with coronary artery disease. Thromb Res, 110: 365-369.

2. Butte NF, Comuzie AG, Cai G, Cole SA, Mehta NR and Bacino CA (2005): Genetic and environmental factors influencing fasting serum adiponectin in Hispanic children. Clin Endocr Metab, 90: 4170-4176.

3. Bjursell M, Ahnmark A, Bohlooly-Y M, William-Olsson L, Rhedin $\mathrm{M}$, Peng $\mathrm{XR}$, Ploj $\mathrm{K}$, Gerdin AK, Arnerup G, Elmgren $A$, Berg AL, Oscarsson $J$ and Lindén D. (2007): Opposing effects of adiponectin receptors 1 and 2 on energy metabolism. Diabetes, 56:583-593.

4. Zhou Y, Sun X, Jin L, Stringfield $T$, Lin $L$ and Chen $Y$ (2005): Expression profiles of adiponectin receptors in mouse embryos. Gene Expr Patterns, 5: 711-715.

5. Yamauchi T, Kamon J, Minokoshi Y, Ito Y, Waki H, Uchida S, Yamashita S, Noda M, Kita S, Ueki K, Eto K, Akanuma Y, Froguel P, Foufelle F, Ferre P, Carling D, Kimura S, Nagai R, Kahn BB and Kadowaki T (2002): Adiponectin stimulates glucose utilization and fatty-acid oxidation by activating AMP activated protein kinase. Nat Med, 8:1288- 1295.

6. Weyer C, Funahashi T, Tanaka S, Hotta K, Matsuzawa Y, Pratley RE and Tataranni PA (2001): Hypoadiponectinemia in obesity and type 2 diabetes: close association with insulin resistance and hyperinsulinemia. $\mathrm{J}$ Clin Endocrinol Metab, 86: 1930-1935.

7. Kojima S, Funahashi T, Maruyoshi H, Honda $\mathbf{O}$, Sugiyama S, Kawano H, Soejima H, Miyamoto S, Hokamaki J, Sakamoto T, Yoshimura M,
Kitagawa A, Matsuzawa $Y$ and Ogawa H. (2005): Levels of the adipocyte-derived plasma protein, adiponectin, have a close relationship with atheroma. Thromb Res, 115 (6):483-490.

8. Kojima S, Funahashi T, Sakamoto T, Miyamoto S, Soejima H, Hokamaki J, Kajiwara I, Sugiyama S, Yoshimura M, Fujimoto K, Miyao Y, Suefuji H, Kitagawa A, Ouchi N, Kihara S, Matsuzawa Y and Ogawa $H$ (2003): The variation of plasma concentrations of a novel adipocyte derived protein, adiponectin, in patients with acute myocardial infarction. Heart, 89:667.

9. Ahima RS and Flier JS (2000): Leptin. Annual Review of Physiology, 62: 413-437.

10. Chan JL, Heist K, DePaoli AM, Veldhuis JD and Mantzoros CS (2003): The role of falling leptin levels in the neuroendocrine and metabolic adaptation to short term starvation in healthy men. Journal of Clinical Investigation, 111: 1409-1421.

11. Zimmet $P$, Hodge A, Nicolson $M$, Staten M, de Courten M, Moore J, Morawiecki A, Lubina J, Collier G, Alberti G \& Dowse G (1996): Serum leptin concentration, obesity and insulin resistance in Western Samoans: cross sectional study. BMJ, 313: 965-969.

12. Otero $M$, Lago $R$, Lago $F$, Casanueva FF, Diequez C, Gomez-Reino JJ and Gualillo $O$ (2005): Leptin from fat to inflammation: old questions and new insights. FEBS Letters, 579: 295-301.

13. Sundell J, Huupponen R, Raitakari OT, Nuutila Pand Knuuti J (2003): High serum 
leptin is associated with attenuated coronary vasoreactivity. Obes Res, 11:776-782.

14. Wolk $R$ and Somers VK (2006): Leptin and vascular function: Friend or foe? Eur Heart J, 27:2263-2265.

15. Friedewald WT, Levy $R$ and, Fredrickson DS (1972): Estimation of the concentration of low-density lipoprotein cholesterol in plasma, without use of the preparative ultracentrifuge. Clin Chem, 18: 499-502.

16. Bogaty P, Brecker SJ, White SE, Stevenson RN, el-Tamimi H, Balcon $R$ and Maseri A (1993): Comparison of coronary angiographic findings in acute and chronic first presentation of ischemic heart disease. Circulation, 87:1938-46.

17. Scanlon PJ, Faxon DP, Audet AM, Carabello B, Dehmer GJ, Eagle KA, Legako RD, Leon DF, Murray JA, Nissen SE, Pepine CJ, Watson RM, Ritchie JL, Gibbons RJ, Cheitlin MD, Gardner TJ, Garson A Jr, Russell RO Jr, Ryan TJ and Smith SC Jr (1999): ACC/AHA guidelines for coronary angiography. A report of the American College of Cardiology/American Heart Association Task Force on practice guidelines (Committee on Coronary Angiography). Developed in collaboration with the Society for Cardiac Angiography and Interventions. J Am Coll Cardio, 33:1756-824

18. Ouchi N, Kihara S, Arita Y, Maeda K, Kuriyama H, Okamoto Y, Hotta $K$, Nishida $M$, Takahashi M, Nakamura T, Yamashita $S$, Funahashi $T$ and Matsuzawa Y (1999): Novel modulator for endothelial adhesion molecules: adipocyte-derived plasma protein adiponectin. Circulation, 100:2473-2476.

19. 19.Nakamura $Y$, Shimada $K$, Fukuda D, Shimada Y, Ehara S, Hirose M, Kataoka T, Kamimori K, Shimodozono S, Kobayashi Y, Yoshiyama $M$, Takeuchi $K$ and Yoshikawa J (2004): Implications of plasma concentrations of adiponectin in patients with coronary artery disease. Heart, 90:528-533.

20. Lim HS, Tayebjee MH, Tan KT, Patel JV, Macfadyen RJ and Lip GY (2005): Serum adiponectin in coronary heart disease: ethnic differences and relation to coronary artery disease severity. Heart, 91:1605-1606.

21. von Eynatten M, Schneider JG, Humpert PM, Kreuzer J, Kuecherer H, Katus HA, Nawroth PP and Dugi KA (2006): Serum adiponectin levels are an independent predictor of the extent of coronary artery disease in men. J Am Coll Cardiol, 47:21242126.

22. Jaleel F, Jaleel A, Aftab J, Rahman MA (2006): Relationship between adiponectin, glycemic control and blood lipids in diabetic type 2 postmenopausal women with and without complication of ischemic heart disease. Clin Chim Acta, 370:76-81.

23. Hara K, Yamauchi T, Imai Y, Manabe I, Nagai R, Kadowaki T ( 2007): Reduced adiponectin level is associated with severity of coronary artery disease. Int Heart J, 48:149-53.

24. Selcuk H, Temizhan A, Selcuk MT, Sen T, Maden O, Tekeli S and Sasmaz A. (2008): Impact of metabolic syndrome on future 
cardiovascular events in patients with first acute myocardial infarction. Coron Artery Dis, 19:79-84

25. Matsuda M, Shimomura I, Sata M, Arita Y, Nishida M, Maeda N, Kumada M, Okamoto Y, Nagaretani $H$, Nishizawa $H$, Kishida K, Komuro R, Ouchi N, Kihara S, Nagai R, Funahashi $T$ and Matsuzawa Y (2002): Role of adiponectin in preventing vascular stenosis. The missing link of adipovascular axis. J Biol Chem, 277:37487-37491.

26. Arita $Y$, Kihara S, Ouchi N, Takahashi M, Maeda K, Miyagawa J, Hotta K, Shimomura I, Nakamura T, Miyaoka $\mathbf{K}$, Kuriyama $\mathbf{H}$, Nishida M, Yamashita S, Okubo K, Matsubara K, Muraguchi M, Ohmoto $Y$, Funahashi $T$ and Matsuzawa Y (1999): Paradoxical decrease of an adipose specific protein, adiponectin, in obesity. Biochem Biophys Res Comm, 257:79-83.

27. Arita Y, Kihara S, Ouchi N, Maeda K, Kuriyama H, Okamoto Y, Kumada M, Hotta K, Nishida M, Takahashi M, Nakamura T, Shimomura I, Muraguchi M, Ohmoto $Y$, Funahashi $T$ and Matsuzawa Y (2002): Adipocytederived plasma protein adiponectin acts as a platelet-derived growth factor-BB-binding protein and regulates growth factor induced common postreceptor signal in vascular smooth muscle cell. Circulation, 105:2893-2898.

28. Birgel $M$, Gottschling-Zeller $H$, Röhrig K and Hauner H (2000): Role of cytokines in the regulation of plasminogen activator inhibitor1 expression and secretion in newly differentiated subcutaneous human adipocytes. Arterioscler Thromb Vasc Biol, 20:1682-1687.

29. Gottschling-Zeller $\mathbf{H}$, Birgel $M$, Röhrig K and Hauner H (2000): Effect of tumor necrosis factor alpha and transforming growth factor beta 1 on plasminogen activator inhibitor-1 secretion from subcutaneous and omental human fat cells in suspension culture. Metabolism, 49:666-671.

30. Okamoto Y, Arita Y, Nishida M, Muraguchi $M$, Ouchi N, Takahashi M, Igura T, Inui Y, Kihara S, Nakamura T, Yamashita S, Miyagawa $\mathbf{J}$, Funahashi $T$ and Matsuzawa $Y$ (2000): An adipocyte-derived plasma protein, adiponectin, adheres to injured vascular walls. Horm Metab Res, 32: 47-50.

31. Chen H, Montagnani $M$, Funahashi T, Shimomura $I$ and Quon MJ (2003): Adiponectin stimulates production of nitric oxide in vascular endothelial cells. J Biol Chem 278: 45021-45026.

32. Kubota N, Terauchi Y, Yamauchi T, Kubota T, Moroi M, Matsui J, Eto K, Yamashita T, Kamon J, Satoh H, Yano W, Froguel P, Nagai R, Kimura S, Kadowaki $T$ and Noda $T(2002)$ : Disruption of adiponectin causes insulin resistance and neointimal formation. J Biol Chem, 277:25863-25866

33. Ouchi N, Kihara S, Arita Y, Nishida M, Matsuyama A, Okamoto Y, Ishigami M, Kuriyama H, Kishida K, Nishizawa H, Hotta K, Muraguchi M, Ohmoto Y, Yamashita S, Funahashi T and, Matsuzawa Y (2001): Adipocyte derived plasma protein, adiponectin, suppresses lipid accumulation and class A 
scavenger receptor expression in human monocyte-derived macrophages. Circulation, 103:1057-1063.

34. Ouchi N, Kihara S, Arita Y, Okamoto Y, Maeda K, Kuriyama H, Hotta K, Nishida M, Takahashi M, Muraguchi M, Ohmoto Y, Nakamura T, Yamashita $S$, Funahashi $T$ and Matsuzawa $Y$ (2000): Adiponectin, an adipocyte-derived plasma protein, inhibits endothelial NF- $\kappa \mathrm{B}$ signaling through a cAMP dependent pathway. Circulation, 102:1296-1301.

35. Snijder MB, van Dam RM, Visser M, Seidell JC (2006): What aspects of body fat are particularly hazardous and how do we measure them? Int J Epidemiol, 35:83-92.

36. Ferreira I, Snijder MB, Twisk JW, van Mechelen W, Kemper HC, Seidell JC, Stehouwer CD (2004): Central fat mass versus peripheral fat and lean mass: opposite (adverse versus favorable) associations with arterial stiffness? The Amsterdam Growth and Health Longitudinal Study. J Clin Endocrinol Metab, 89: 2632-2639.

37. Parhami F, Tintut Y, Ballard A, Fogelman AM and Demer LL (2001): Leptin enhances the calcification of vascular cells: artery wall as a target of leptin. Circ Res, 88:954-960.

38. Montague CT, Prins JB, Sanders L, Zhang J, Sewter CP, Digby J, Byrne CD and O'Rahilly $S$ (1998): Depot-related gene expression in human subcutaneous and omental adipocytes. Diabetes, 47:1384-1391.

39. Arner $P$ (1995): Differences in lipolysis between human subcutaneous and omental adipose tissues. Ann Med;27:435-438.

40. Alessi MC, Peiretti F, Morange P, Henry M, Nalbone G, JuhanVague I (1997): Production of plasminogen activator inhibitor 1 by human adipose tissue: possible link between visceral fat accumulation and vascular disease. Diabetes, 46:860-867.

41. Dusserre E, Moulin P, Vidal H (2000): Differences in mRNA expression of the proteins secreted by the adipocytes in human subcutaneous and visceral adipose tissues. Biochim Biophys Acta, 1500:88-96.

42. Elsayed EF, Tighiouart $H$, Weiner DE, Griffith J, Salem D, Levey AS and Sarnak MJ (2008): Waist-to-hip ratio and body mass index as risk factors for cardiovascular events in CKD. Am J Kidney Dis,52:49-57.

43. Widlansky ME, Gokce N, Keaney JF Jr. and Vita JA (2003): The clinical implications of endothelial dysfunction. J Am Coll Cardiol;42: 1149-60.

44. Lerman $A$ and Zeiher AM (2005): Endothelial function: cardiac events. Circulation, 111:363-8.

45. Wallace AM, McMahon AD, Packard CJ, Kelly A, Shepherd J, Gaw A, Sattar N ( 2001): Plasma leptin and the risk of cardiovascular disease in the west of Scotland coronary prevention study (WOSCOPS). Circulation, 104:3052-3056.

46. Wolk R, Berger P, Lennon RJ, Brilakis ES, Johnson BD and Somers VK (2004): Plasma leptin and prognosis in patients with established coronary atherosclerosis. J Am Coll Cardiol, 44:1819-1824. 
47. Matsuda $\mathrm{K}$, Teragawa $\mathrm{H}$, Fukuda Y, Nakagawa K, Higashi $Y$ and Chayama K (2003): Leptin causes nitric-oxide independent coronary artery vasodilation in humans. Hypertens Res, 26:147-152

48. Couillard $C$, Lamarche $B$, Mauriege P, Cantin B, Dagenais GR, Moorjani S, Lupien PJ and Despres JP (1998): Leptinemia is not a risk factor for ischemic heart disease in men. Prospective results from the Quebec Cardiovascular Study.Diabetes Care, 21:782-786

49. Piemonti L, Calori G, Mercalli A, Lattuada G, Monti P, Garancini MP, Costantino F, Ruotolo G, Luzi $L$ and Perseghin $G$ (2003): Fasting plasma leptin, tumor necrosis factor- $\alpha$ receptor 2 , and monocyte chemoattracting protein 1 concentration in a population of glucose-tolerant and glucoseintolerant women: impact on cardiovascular mortality. Diabetes Care, 26:2883-2889

50. Sierra-Honigmann MR, Nath AK, Murakami C, GarciaCardena G, Papapetropoulos A, Sessa WC, Madge LA, Schechner JS, Schwabb MB, Polverini PJ and Flores-Riveros JR (1998): Biological action of leptin as an angiogenic factor. Science, 281:1683-1686.

51. Bouloumie A, Marumo $T$, Lafontan $M$ and Busse $R$ (1999): Leptin induces oxidative stress in human endothelial cells. FASEB J,13:1231- 1238 .

52. Cooke JP and Oka RK (2002): Does leptin cause vascular disease? Circulation, 106:1904-1905.

53. Wolf G, Hamann A, Han DC, Helmchen U, Thaiss F, Ziyadeh FN and Stahl RA (1999): Leptin stimulates proliferation and TGFbeta expression in renal glomerular endothelial cells: potential role in glomerulosclerosis. Kidney Int, 56:860-872.

54. Li L, Mamputu JC, Wiernsperger $\mathbf{N}$ and Renier $\mathbf{G}$ (2005): Signaling pathways involved in human vascular smooth muscle cell proliferation and matrix metalloproteinase-2 expression induced by leptin: inhibitory effect of metformin. Diabetes, 54:22272234.

55. Quehenberger $P$, Exner $M$, Sunder-Plassmann R, Ruzicka K, Bieglmayer C, Endler G, Muellner C, Speiser $\mathbf{W}$ and Wagner O (2002): Leptin induces endothelin-1 in endothelial cells in vitro. Circ Res, 90:711-718.

56. Thogersen AM, Soderberg S, Jansson JH, Dahlén G, Boman K, Nilsson TK, Lindahl B, Weinehall L, Stenlund $\mathrm{H}$, Lundberg V, Johnson O, Ahrén $B$ and Hallmans $G$ (2004): Interactions between fibrinolysis, lipoproteins and leptin related to a first myocardial infarction. Eur $\mathrm{J}$ Cardiovasc Prev Rehabil,11:3340.

57. Chu NF, Spiegelman D, Hotamisligil GS, Rifai N, Stampfer $M$ and Rimm EB (2001): Plasma insulin, leptin, and soluble TNF receptors levels in relation to obesity related atherogenic and thrombogenic cardiovascular disease risk factors among men. Atherosclerosis, 157: 495-503.

58. Soderberg $\mathbf{S}$, Olsson $\mathbf{T}$, Eliasson $M$, Johnson $O$ and Ahrén $B$ (1999): Plasma leptin levels are associated with abnormal fibrinolysis in men and postmenopausal women. J Intern Med, 245:533-543. 
59. Corsonello A, Perticone F, Malara A, De Domenico D, Loddo S, Buemi $M$, Ientile $R$, Corica $F$ (2003): Leptin-dependent platelet aggregation in healthy, overweight and obese subjects. Int J Obes Relat Metab Disord, 27:566 -573 .

60. Loffreda $S$, Yang SQ, Lin HZ, Karp CL, Brengman ML, Wang DJ, Klein AS, Bulkley GB, Bao $C$, Noble $P W$, Lane $M D$, and Diehl AM (1998): Leptin regulates proinflammatory immune responses. FASEB J, 12: 57-65.

61. Maingrette $F$ and Renier $G$ (2003): Leptin increases lipoprotein lipase secretion by macrophages: involvement of oxidative stress and protein kinase C. Diabetes, 52:2121-2128.

62. O'Rourke L, Yeaman SJ and Shepherd PR (2001): Insulin and leptin acutely regulate cholesterol ester metabolism in macrophages by novel signaling pathways. Diabetes, 50:955-961.

63. Lundasen $T$, Liao $W$, Angelin $B$ and Rudling $M$ (2003): Leptin induces the hepatic high density lipoprotein receptor scavenger receptor B type I (SR-BI) but not cholesterol 7 $\alpha$-hydroxylase (Cyp7a1) in leptin deficient (ob/ob) mice. J Biol Chem, 278: 4322443228.

64. Shamsuzzaman ASM, Winnicki M, Wolk R, Svatikova A, Phillips $B$, Berger $P$ and Somers VK
(2004): An independent association between plasma leptin and Creactive protein in healthy humans. Circulation, 109: 2181-2185.

65. Momin AU, Melikian N, Shah AM, Grieve DJ, Wheatcroft SB, John L, El Gamel A, Desai JB, Nelson T, Driver C, Sherwood RA and Kearney MT (2006): Leptin is an endothelial independent vasodilator in humans with coronary artery disease: evidence for tissue specificity of leptin resistance. Eur Heart J, 27:2294-2299.

66. Vecchione C, Maffei A, Colella S, Aretini A, Poulet R, Frati G, Gentile MT, Fratta L, Trimarco $V$, Trimarco $B$ and Lembo $G$ (2002): Leptin effect on endothelial nitric oxide is mediated through Akt-endothelial nitric oxide synthase phosphorylation pathway. Diabetes, 51: 168-173.

67. Wolk R, Deb A, Caplice NM and Somers VK (2005): Leptin receptor and functional effects of leptin in human endothelial progenitor cells. Atherosclerosis, 183:131-139.

68. O'Rourke L, Gronning LM, Yeaman SJ and Shepherd PR (2002): Glucosedependent regulation of cholesterol ester metabolism in macrophages by insulin and leptin. J Biol Chem, 277:42557-42562. 


\section{الاديبونكتن والليتين في المصل كمؤشرات للتنبؤ بوجود و درجة تصلب الثر ايين التاجية}

$$
\begin{aligned}
& \text { نشوى علي عبد المطلب ، وحسام حسن علي *، حسني بدر اوي حامد ** ، }
\end{aligned}
$$

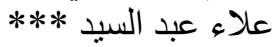

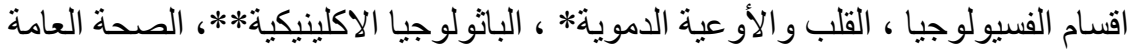

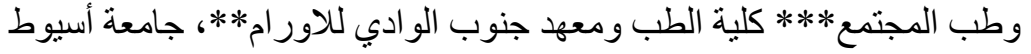

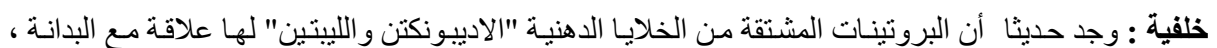

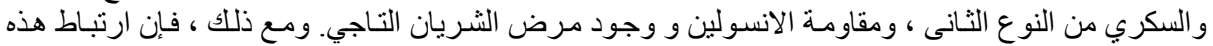

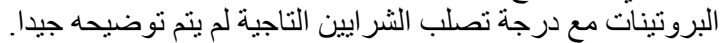

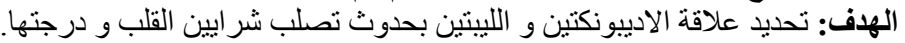

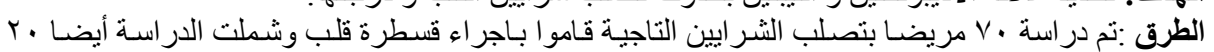

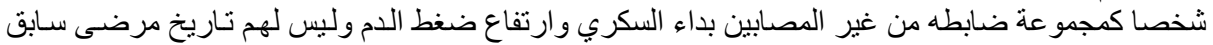

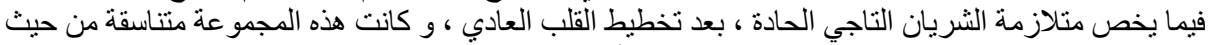

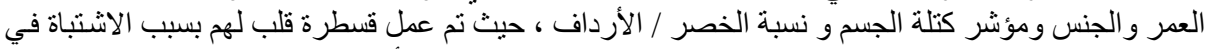

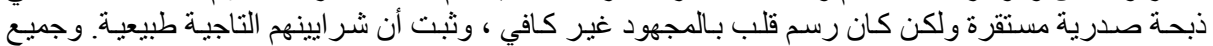

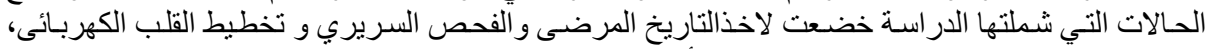

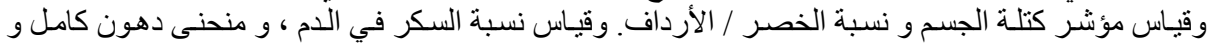

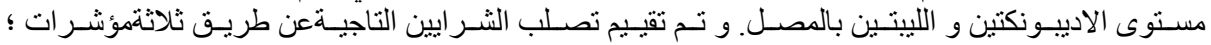
شدةالانسداد، وطوله ونمطه (التعقيد).

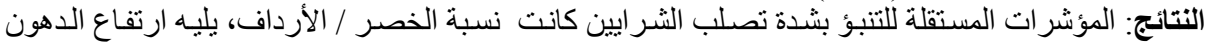

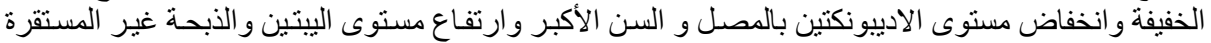

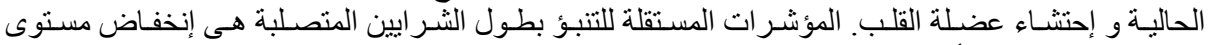
الاديبونكتين بالمصل (أهم المؤشر ات المستقلة)، يليه ارتفاع نسبة الدهون الخفيفة و السن الكبير و إحتثاء عضلة

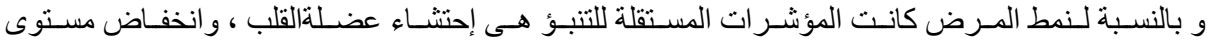
الادييونكتين بالمصل، نسبة الخصر / الأرداف، و إرتفاع الليبتين بالمصل و السن الكبير الكبير وارتفاع مستوى السكر

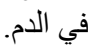
الآستتناج : يمكن أن يلعب كل من الاديبونكتن و الليبتين دور الهاما ليس فقط في حدوث تصلب الثر ايين التاجية ولكن أيضا في شدنها ، ومداها و تعقيد نمطها. 